MaPan : Jurnal Matematika dan Pembelajaran

p-ISSN: 2354-6883; e-ISSN: 2581-172X

Volume 8, No 1, June 2020 (87-102)

DOI: https://doi.org/10.24252/mapan.2020v8n1a7

\title{
ADVERSITY QUOTIENT AND RESILIENCE IN MATHEMATICAL PROOF PROBLEM-SOLVING ABILITY
}

\author{
Fauziah Hakim ${ }^{1}$, Murtafiah ${ }^{2}$ \\ 1,2Program Studi Pendidikan Matematika, Universitas Sulawesi Barat \\ 1,2Jl. Baurung, Banggae Timur, Kabupaten Majene, Sulawesi Barat \\ E-mail: fauziahhakim@unsulbar.ac.id1),murtafiah@unsulbar.ac.id²), \\ Received May 6, 2020; Revised June 16, 2020; Accepted June 20, 2020
}

\begin{abstract}
:
Various mathematical abilities require a high level of struggle to be achieved, one of which is the ability to solve mathematical proof problems. Several factors are also associated with this ability, including adversity quotient and resilience. This research aimed to look at the effect of adversity quotient and resilience on the mathematical proof problem-solving ability. This research used a quantitative approach with a correlational method. The sample in this study were 31 students randomly selected from all students of the Mathematics Education Study Program at Universitas Sulawesi Barat who programmed Abstract Algebra course in the academic year of 2019/2020, amounting to 71 students. The analysis technique used is multiple linear regressions. The results of hypothesis testing indicate that adversity quotient and resilience affect the mathematical proof problem-solving ability positively both individually and simultaneously.
\end{abstract}

Keywords: Adversity Quotient, Resilience, Problem-Solving, Mathematical Proof

\section{ADVERSITY QUOTIENT DAN RESILIENSI DALAM KEMAMPUAN PEMECAHAN MASALAH PEMBUKTIAN MATEMATIS}

\begin{abstract}
Abstrak:
Berbagai kemampuan matematis memerlukan daya juang tinggi untuk berhasil dicapai, salah satunya kemampuan pemecahan masalah pembuktian matematis. Beberapa faktor pun dikaitkan dengan kemampuan tersebut, antara lain adversity quotient dan resiliensi. Penelitian ini bertujuan untuk melihat pengaruh adversity quotient dan resiliensi terhadap kemampuan pemecahan masalah pembuktian matematis. Penelitian ini menggunakan pendekatan kuantitatif dengan metode korelasional. Sampel pada penelitian ini sebanyak 31 mahasiswa yang dipilih secara acak dari seluruh mahasiswa Program Studi Pendidikan Matematika Universitas Sulawesi Barat yang memprogramkan mata kuliah Struktur Aljabar tahun akademik 2019/2020 yang berjumlah 71 mahasiswa. Teknik analisis yang digunakan adalah regresi linear berganda. Hasil pengujian hipotesis menunjukkan bahwa adversity quotient dan resiliensi berpengaruh positif terhadap kemampuan pemecahan masalah pembuktian matematis baik secara sendiri-sendiri maupun secara simultan.
\end{abstract}

Kata kunci: Adversity Quotient, Resiliensi, Pemecahan Masalah, Pembuktian Matematis 
How to Cite: Hakim, F., \& Murtafiah (2020). Adversity Quotient and Resilience in Mathematical Proof. MaPan: Jurnal Matematika dan Pembelajaran, 8(1), 87-102. https://doi.org/10.24252/mapan.2020v8n1a7.

\section{INTRODUCTION}

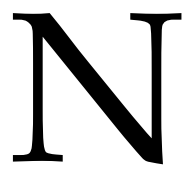

ot only at the elementary and secondary level, mathematical problemsolving is also a problem at the undergraduate level, even for mathematics class students. Many studies conducted at the elementary school level show that students' mathematical problem-solving abilities are still low. The results of the observation of Indarwati, Wahyudi, \& Ratu (2014) showed that many fifth grade students were unable to work on problem-solving problems in calculating operations, as well as the results of trials conducted by Novianti \& Kurniadi (2016) that the majority of students had difficulty working on problem-solving, especially in the form of word problems. Furthermore, it was revealed that the low ability of these students was because at the elementary school level, students were accustomed to being given the fastest formula in solving a problem, not using mathematical concepts (Rostika \& Junita, 2017; Mustafia \& Widodo, 2018). According to Mulyati (2011), the low mathematical problem-solving ability of elementary school students is an indication of the low mathematical problem-solving ability of students at the secondary level. As for the undergraduate level, various previous studies related to mathematical problem-solving at the undergraduate level (Ningsih, 2017; Octaria \& Sari, 2017; Amalia \& Widodo, 2018; Gurat, 2018) showed that students' mathematical problem-solving ability is still low. In fact, mathematical problem-solving is a goal and the result of the teaching and learning process, which is very important. There is no mathematics without thinking, and there is no thought process without problems (Aljaberi, 2015). Mathematical problemsolving has long been seen as an important aspect of mathematics, teaching mathematics, and learning mathematics (Liljedahl, Santos-Trigo, Malaspina, \& Bruder, 2016). Problem-solving plays an important role in mathematics education and most mathematics learning is the result of the problem-solving process (Ersoy, 2016). According to Arvanitakis \& Hornsby (2016), there are some general skills that universities try to develop at the student level. The term "Citizen Scholar" is introduced to describe graduates who have key skills in the form of critical thinking skills, communication skills, problem-solving, research, and collaboration that will help students adapt to the changing needs of society. 
In many subjects, the problem of mathematical proof is one of the mathematical problems often faced by undergraduate students. Ozdemir \& Ovez (2012) suggested that in preparing formal mathematical proofs, there were still many serious difficulties faced by prospective mathematics teacher students. Mathematical evidence provides guarantees for mathematical knowledge and is an important activity in doing and understanding mathematics. Proof is a tool in learning mathematics. Proof has an important role in many courses in the Department of Mathematics. According to Hanna \& Barbeau (2010), mathematical propositions can be said to be true if they have been proven. Stefanowicz (2014) also revealed that the essence of mathematics learning is proof. Lesseig, Hine, \& Boardman, (2019) who argue "the centrality of proof of mathematics is indisputable." Some opinions also suggested the importance of mathematical proof (Balacheff, 2010; Basturk, 2010; CadwalladerOlsker, 2011; Rocha, 2019). However, Mukmin \& Fa'ani (2020) found the fact that in solving mathematical proof problems, there were still so many misconceptions faced by students that resulted in the low mathematical proof ability of students. Some preliminary studies that have been conducted also showed the low mathematical proof ability of undergraduate students (Abdussakir, 2014; Hasan, 2016; Muliawati, 2018; Nurrahmah \& Karim, 2018; Herutomo, 2019). Mathematical proof requires a high level of ability that requires great effort to be able to get it (Hasan, 2016). The difficulty faced by students in understanding mathematical proofs depends on how the students process information and then solve the problem. In addition, the success of students in solving mathematical proof problems also depends on whether they will surrender or conquer the difficulties or continue to struggle to conquer the difficulties encountered.

One of the factors that influence hard work in solving problems is adversity quotient. Many people have high IQ and EQ, but they fail. This is due to the low adversity quotient (AQ) (Stoltz, 2004). In psychological studies, adversity quotient (AQ) is a person's ability to survive in the face of difficulties and efforts to resolve difficulties (Hastuti \& Sari, 2017). If related to the learning process, then AQ is needed for learners in dealing with problems in learning (Matore, Khairani, \& Razak, 2015). Learners who have a good AQ, can survive in the face of various difficulties in learning mathematics. Therefore, it is necessary to study AQ in learning mathematics (Parvathy \& Praseeda, 2014). Various opinions regarding AQ have also been expressed by several previous 
researchers (Rukmana, Hasbi, \& Paloloang, 2016; Mardika \& Insani, 2017; Qin, Zhou, \& Tanu, 2019).

There are 3 categories in $A Q$, namely quitter (low $A Q$ ), camper (medium $A Q)$, and climber (high AQ). Climbers choose to survive and struggle to face the problems, challenges, and obstacles that will continue to hit, campers have the willingness to try to deal with problems, challenges, and obstacles but stop because they feel they are no longer able, while the quitters lack the ability to accept challenges in life. AQ consists of four dimensions used to measure and understand AQ and in determining the level of adversity quotient, control, origin and ownership, reach, and endurance termed CO2RE (Stoltz, 2004).

Another factor related to hard work in solving problems is resilience. Rojas (2015) stated resilience as the ability to face challenges that will be seen when someone is facing a difficult experience and knows how to deal with or adapt to it. In relation to the world of education, especially problem-solving, according to Maharani \& Bernard (2018), students are afraid and avoid challenging problem-solving because of difficulties in working on problemsolving problems. This fear causes anxiety for students and they need to have a strong, persistent, and confident attitude called resilience. Reivich \& Shatte (2002) suggested that seven abilities make up resilience, namely (1) emotional control, (2) ability to control impulses, (3) optimism, (4) ability to analyze, (5) ability to empathize, (6) self-efficacy, and (7) ability to achieve what is desired.

Adversity quotient and resilience, which are factors related to hard work to face challenges, make research to see the effect of these two variables on the ability to solve mathematical proof problems very interesting to do. This research is very important to be carried out as a first step to improve students' mathematical proof proving ability. It takes data related to what factors affect the ability of these students. Several related studies have been conducted by other researchers related to this research. Rukmana, Hasbi, \& Paloloang (2016) found that there is a significant positive relationship between adversity quotient with student mathematics learning outcomes. This is supported by the results of Mardika \& Insani's research (2017), it was found that problem-solving ability has a relationship with adversity quotient. Regarding resilience factors, (Zanthy, 2018) found that resilience has a positive contribution to students' academic abilities in Mathematics Statistics. Some researchers have conducted various studies related to these three variables, but separately. This study will examine at the same time, the relationship between adversity quotient and resilience with the mathematical proof problem-solving ability. Research hypotheses to be 
tested are (1) there is an effect of adversity quotient on the ability to solve mathematical proof problems, (2) there is an effect of resilience on the ability to solve mathematical proof problems, and (3) there is an effect of adversity quotient and resilience simultaneously on the ability to solve mathematical proof problem.

\section{RESEARCH METHOD}

This research was a correlational study with a quantitative approach that aimed to determine the effect of adversity quotient and resilience on the ability to solve mathematical proof problems. The samples in this study were 31 students chosen randomly from all students of the Mathematics Education Study Program at Universitas Sulawesi Barat who programed Abstract Algebra courses in the academic year 2019/2020, amounting to 71 students. Researchers collected research data during the COVID-19 pandemic, so it was not possible to make the entire population a sample in this research. This size of the research sample is consistent with several theories regarding sample size. Roscoe (1975) revealed that the sample size used was at least 10 times the number of factors if there were many factors in the research. Gay \& Diehl (1992) argue that at least 30 sample units are used if research is correlational research.

The non-test instrument in this research was the Quick Take ${ }^{\mathrm{TM}}$ Adversity Response Profile (ARP), a test by Stoltz (2004), which has been tested by more than 7,500 people from all over the world with various careers, ages, races, and cultures. After repeated and continuous tests, this instrument proved to be very reliable. This instrument was used to obtain an adversity quotient score. The second non-test instrument was Resilience Factor Inventory (RFI), a test that was successfully developed by Reivich \& Shatte (2002) and has been used extensively throughout the world. This instrument was used to obtain resilience scores. As for the test instrument used was a mathematical proof problemsolving test with Group Theory materials.

The data analysis technique used in this research was multiple linear regression analysis with the assumption test consisting of tests of normality, multicollinearity, autocorrelation, and heteroscedasticity. Then used partial regression coefficient test (t-test) to see the effect of the independent variables (adversity quotient and resilience) on the dependent variable (mathematical proof problem-solving ability), regression coefficient test together ( $F$ test) to see the effect of independent variables on the dependent variable simultaneously, multiple correlation analysis $(\mathrm{R})$ to determine the type and category of influence 
between the independent variables on the dependent variable, and the analysis of determination (adjusted R2) to determine the percentage contribution of the influence of the independent variable simultaneously on the dependent variable. The analysis was carried out by a two-party test using a significance level of 5\%. Analyzes were performed using IBM SPSS Statistics 21.

\section{RESULTS AND DISCUSSION}

The theory presented in the previous section revealed that AQ can be classified into 3 categories, and based on research data, the classification results are obtained as in figure 1 below.

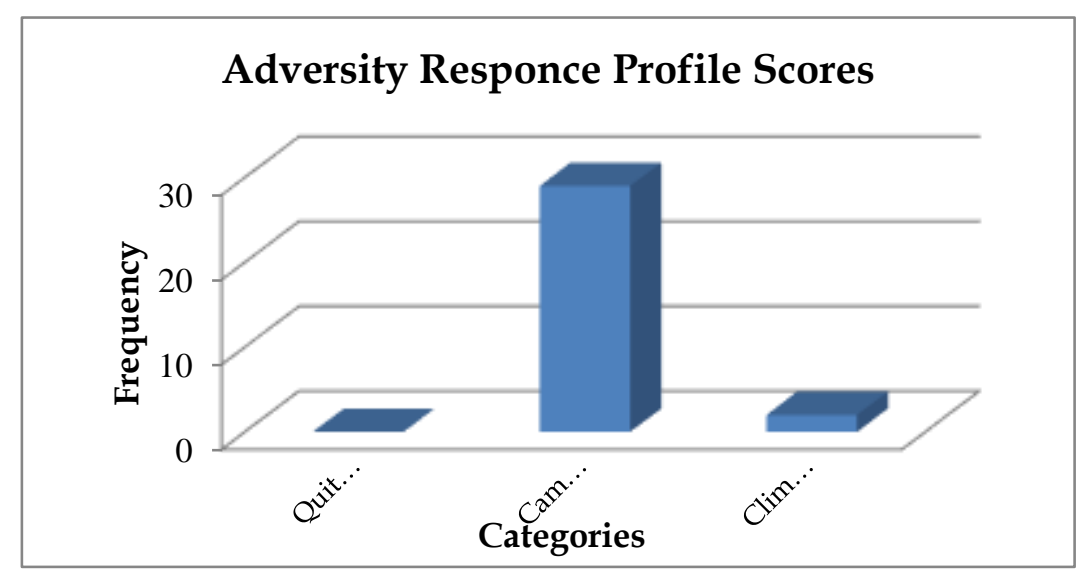

Figure 1. AQ Categories

The resilience data obtained are categorized and presented in figure 2 below.

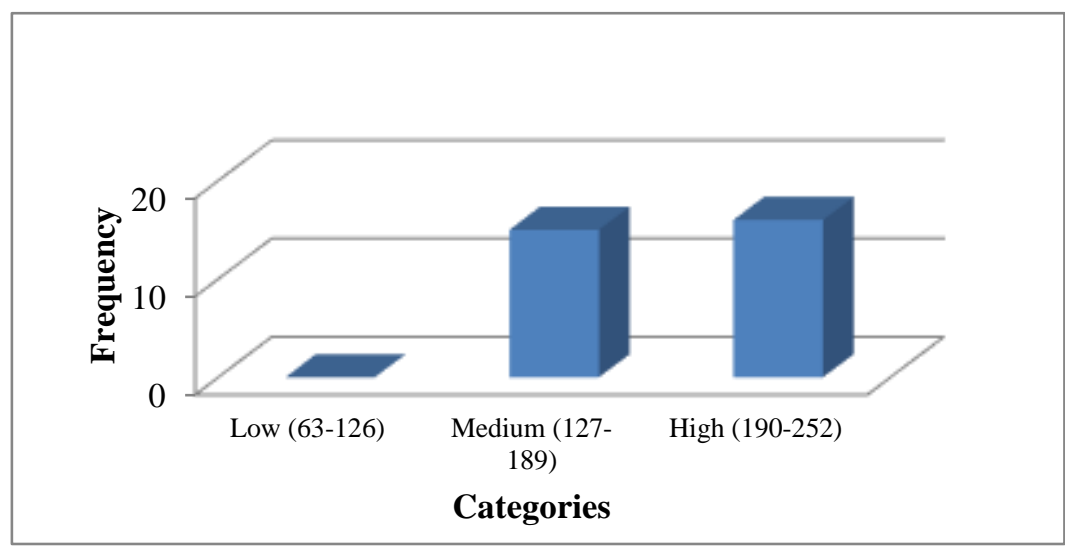

Figure 2. Resilience Categories 
The mathematical proof problem-solving ability data are categorized as in figure 3 below.

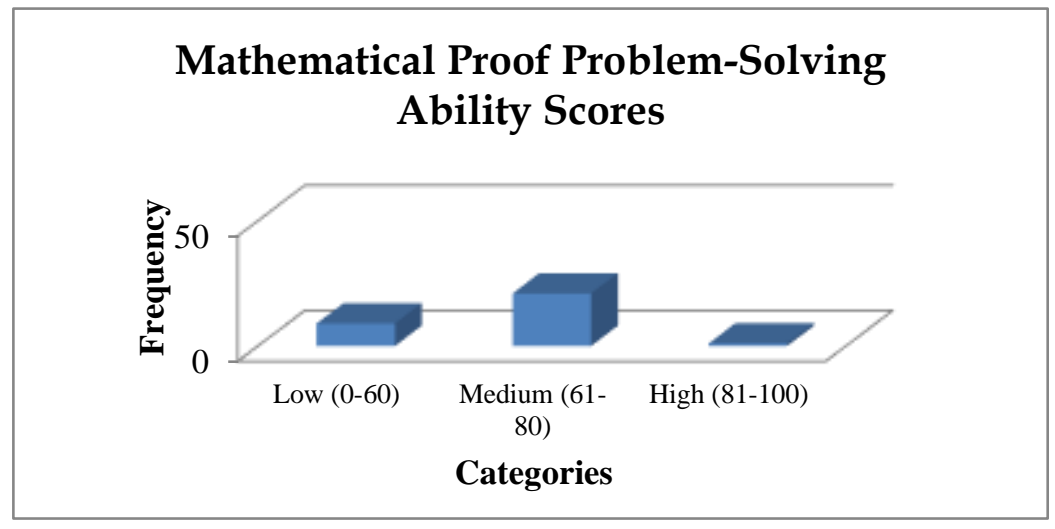

Figure 3. Mathematical Proof Problem-Solving Ability Categories

The first assumption test, the normality test, gave the results of adversity quotient, resilience, and mathematical problem-solving ability variables data in table 1.

Table 1. Summary of Normality Tests Results

\begin{tabular}{cccc}
\hline & \multicolumn{3}{c}{ Shapiro-Wilk } \\
\cline { 2 - 4 } & Statistic & $\mathrm{df}$ & Sig. \\
ARP_Score & .970 & 31 & .528 \\
RFI_Score & .957 & 31 & .236 \\
PMPM_Score & .967 & 31 & .434 \\
\hline
\end{tabular}

Based on the data in table 1, the significance for the ARP score (adversity quotient score) is 0.528 , the significance for the RFI score (resilience score) was 0.236 , and the significance for the mathematical proof-solving ability problem score is 0.434 . Because all three variables have a significance value of more than 0.05 , it can be concluded that all three data (adversity quotient, resilience, and the ability to solve mathematical proofs) come from normally distributed populations. For the second assumption test, multicollinearity test between independent variables, the results are summarized in the following table 2.

Table 2. Summary of Multicollinearity Test

\begin{tabular}{|c|c|c|c|}
\hline \multirow{2}{*}{\multicolumn{2}{|c|}{ Model }} & \multicolumn{2}{|c|}{ Collinearity Statistics } \\
\hline & & Tolerance & VIF \\
\hline \multirow[t]{3}{*}{1} & (Constant) & & \\
\hline & ARP_Score & .978 & 1.022 \\
\hline & RFI_Score & .978 & 1.022 \\
\hline
\end{tabular}


Based on the data in table 2, it is known the VIF variable adversity quotient $(1,022)$ and VIF resilience variable $(1,022)$. Because the VIF value for all variables is less than 10 , it can be concluded that there is no multicollinearity disorder. For the autocorrelation test results, the third assumption test, the results are summarized in the following table 3.

Table 3. Summary of Autocorrelation Test

\begin{tabular}{cccccc}
\hline Model & $\mathbf{R}$ & R Square & $\begin{array}{c}\text { Adjusted } \\
\text { R Square }\end{array}$ & $\begin{array}{c}\text { Std. Error of } \\
\text { the Estimate }\end{array}$ & $\begin{array}{c}\text { Durbin- } \\
\text { Watson }\end{array}$ \\
$\mathbf{1}$ & $.524^{\mathrm{a}}$ & .275 & .223 & 8.258 & 1.727 \\
\hline
\end{tabular}

Based on the data in table 3, the Durbin-Watson (DW) value obtained is 1,727. The Durbin Lower (DL) and Durbin Upper (DU) values obtained from the Durbin-Watson Table are 1.29685 and 1.57011, respectively. Because DW> DU, there is no positive autocorrelation and because $(4-\mathrm{DW})>\mathrm{DU}$, there is no negative autocorrelation. While the heteroscedasticity test results are summarized in the following figure 4 .

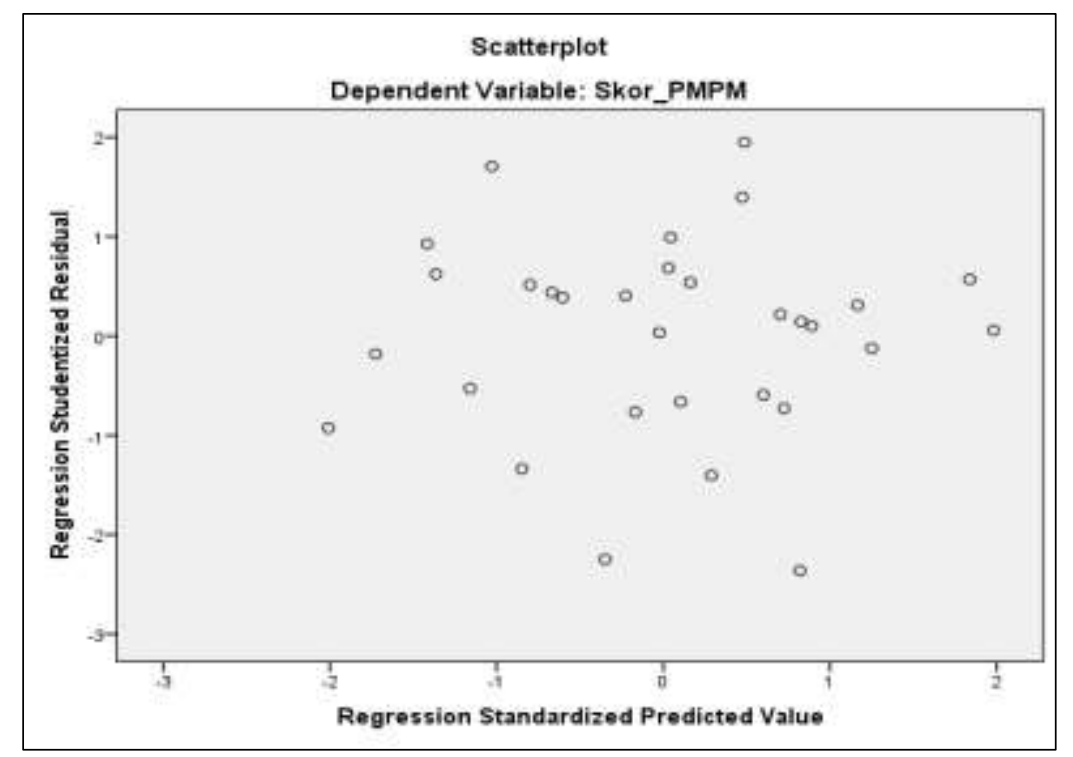

Figure 4. Result of Heteroscedasticity Test

Heteroscedasticity test results show that the data do not form a specific pattern and are spread above and below the number 0 . So it can be concluded that there are no symptoms of heteroscedasticity. Thus all assumption tests for multiple linear regression tests are met. 
The equation of multiple linear regression obtained is

$$
Y^{\prime}=-47,471+0,303 X_{1}+0,387 X_{2}
$$

with:

$Y^{\prime}=$ Mathematical Proof Problem-Solving Ability Variable

$\mathrm{X}_{1}=$ Adversity Quotient Variable

$\mathrm{X}_{2}=$ Resilience Variable table 4 .

Constants and equation coefficients in (1) are obtained from the following

Tabel 4. Summary of Coefficients

\begin{tabular}{clccc}
\hline \multirow{2}{*}{ Model } & \multicolumn{2}{c}{$\begin{array}{c}\text { Unstandardized } \\
\text { Coefficients }\end{array}$} & $\begin{array}{c}\text { Standardized } \\
\text { Coefficients }\end{array}$ \\
\cline { 3 - 5 } 1 & & B & Std. Error & Beta \\
& (Constant) & -47.471 & 35.636 & \\
& ARP_Score & .303 & .123 & .400 \\
& RFI_Score & .387 & .157 & .402 \\
\hline
\end{tabular}

The results of the partial regression coefficient test (t-test) to see the effect of individual independent variables (adversity quotient and resilience) on the dependent variable (mathematical proof of problem-solving ability) are summarized in the following table 5.

Table 5. Result of Partial Regression Coefficient Test (t-test)

\begin{tabular}{rlcc}
\hline & Model & T & Sig. \\
\multirow{2}{*}{1} & (Constant) & -1.332 & .194 \\
& Skor_ARP & 2.459 & .020 \\
& Skor_RFI & 2.472 & .020 \\
\hline
\end{tabular}

In table 5, it can be seen that the significance value for the adversity quotient variable is 0.020 . Because the significance is less than 0.05 , it can be concluded that at a significance level of $5 \%$, there is a significant effect of adversity quotient on the ability to solve mathematical proofs. The significance of the resilience variable is 0.020 . Since the significance is less than 0.05 , it can be concluded that at a significance level of $5 \%$, there is a significant effect of resilience on the ability to solve mathematical proofs. 
Next, to test the effect of simultaneous independent variables (adversity quotient and resilience) on the dependent variable (the ability to solve mathematical proof problems), a regression coefficient test is conducted together (F test) with the results summarized in table 6.

Table 6. Result of Regression Coefficient Test Simultaneously (F test)

\begin{tabular}{ccccccc}
\hline \multirow{2}{*}{ Model } & $\begin{array}{c}\text { Sum of } \\
\text { Squares }\end{array}$ & df & $\begin{array}{c}\text { Mean } \\
\text { Square }\end{array}$ & F & Sig. \\
\hline \multirow{2}{*}{$\mathbf{1}$} & Regression & 722.610 & 2 & 361.305 & 5.298 & $.011^{\mathrm{b}}$ \\
\cline { 2 - 5 } & Residual & 1909.584 & 28 & 68.199 & & \\
\hline
\end{tabular}

In table 6, it appears that the significance value is 0.011 . Because the significance is less than 0.05 , it can be concluded that at a significance level of $5 \%$, there is a significant effect of adversity quotient and resilience simultaneously on the ability to solve mathematical proofs.

Furthermore, to determine the types and categories of influence of the independent variables on the dependent variable simultaneously multiple correlation analysis $(\mathrm{R})$ is used and to determine the percentage of the contribution of the independent variable simultaneously on the dependent variable the determination analysis (adjusted R2) is used with the results summarized in table 7 .

Table 7. Result of Multiple Correlation Analysis (R) dan Determination Analysis (adjusted $R^{2}$ )

\begin{tabular}{ccccc}
\hline Model & $\mathbf{R}$ & R Square & $\begin{array}{c}\text { Adjusted } \mathbf{R} \\
\text { Square }\end{array}$ & $\begin{array}{c}\text { Std. Error of the } \\
\text { Estimate }\end{array}$ \\
\hline $\mathbf{1}$ & $.524^{\mathrm{a}}$ & .275 & .223 & 8.258 \\
\hline
\end{tabular}

Based on table 7 , the value of $R$ is 0.524 . This shows that the effect of adversity quotient and resilience simultaneously on the ability to solve mathematical proof problems is a positive influence and is in the medium category. The adjusted R2 value obtained is 0.223 . This shows that the percentage contribution of the effect of variable adversity quotient and resilience simultaneously on the ability to solve mathematical proof problems by $22.3 \%$.

The results obtained in the multiple linear regression test showed that there was an effect of adversity quotient and resilience on the ability to solve 
mathematical proofs, both individual and simultaneous influences. Furthermore, the coefficients of the two variables in the multiple linear regression equation are positive so that it can be concluded that adversity quotient has a positive effect on the ability to solve mathematical proofs and resilience has a positive effect on the ability to solve mathematical proofs. It can also be concluded that adversity quotient and resilience simultaneously have a positive effect on the ability to solve mathematical proofs and the effect is in the moderate category.

Different efforts and attitudes by students when solving mathematical proof problems have a positive effect on adversity quotient on the ability to solve mathematical proof problems. Student climbers, campers, and quitters have different efforts and attitudes in solving mathematical proofs. Climber students will make a concerted effort to solve the problem, camper students have an effort to solve the problem but will leave it when it finds the problem getting complicated, while the quitter really will not make an effort to solve the problem because they think they will not be able to solve the problem. Qin, Zhou, \& Tanu (2019) revealed that adversity quotient is the greatest strength of a learner to solve existing problems. In addition, several research findings also support this finding. Oliveros (2014) revealed that adversity quotient determines the level of achievement that students ultimately achieve in challenging tasks such as solving mathematical problems. Mardika \& Insani (2017) also concluded that adversity quotient has a relationship with problemsolving abilities. Malik, Mulyono, \& Mariani (2019) argue that the success of problem-solving learning is not only influenced by IQ and EQ, but also by AQ.

In addition to adversity quotient, resilience also has a positive effect on the ability to solve mathematical proofs. According to Murphey, Barry, \& Vaughn (2013), someone who has a different level of resilience, will have different characteristics. One of the characteristics of someone who has high resilience is to have good thinking skills (intelligence). Dilla, Hidayat, \& Rohaeti (2018) concluded in the results of their study that there is a positive influence between resilience and gender differences in the achievement of students' mathematical creative thinking abilities. As for thinking skills affect the ability to solve mathematical proof problems. Suhendris' (2018) research results show that there is an influence, although not significant, resilience and mathematical creativity on the ability to solve mathematical problems. Rojas (2015) suggests that by growing resilience, people can develop lifelong skills such as communication and problem-solving skills, the ability to make realistic plans, 
and be able to follow up on those plans. The influence of resilience on problemsolving abilities was also stated by Supardi (2014), who revealed that resilience is an attitude to recognize a problem and its causes.

Mathematics education is a discipline that is closely related to various disciplines, one of which is psychology. Nevertheless, the relationship between mathematics and psychology education is still debated (Obersteiner, Reiss, \& Heinze, 2018). Star \& Rittle-Johnson (2016) put forward the fact that we are currently in the midst of a new phase in the relationship between the disciplines of mathematics education and psychology. Thus, research on psychology needs to be done in the policy and teaching of mathematics education. The results obtained in this study also indicated psychological aspects that have a relationship with the mathematical problem-solving in specific and towards mathematics education in general. Psychological aspects must be a special concern of educators in the world of mathematics education because through various related studies also find facts related to psychological aspects and various mathematical abilities.

\section{CONCLUSION}

Adversity quotient and resilience affect the ability to solve mathematical proof problems, both the effect of individual adversity quotient and resilience on the ability to solve mathematical proof problems, as well as simultaneous influence. It was further found that the effect of adversity quotient and resilience on the ability to solve mathematical proof problems individually was a positive influence and the effect of adversity quotient and resilience on the ability to solve mathematical proofs simultaneously was a positive influence and was in the medium category.

\section{REFERENCES}

Abdussakir, A. (2014). Proses berpikir mahasiswa dalam menyusun bukti matematis dengan strategi semantik. Journal of Science, Mathematics, and Vocational Education, 2(3), 132-140. http://doi.org/10.17977/jps. v2i3.4506.

Aljaberi, N. M. (2015). University students' learning styles and their ability to solve mathematical problems. International Journal of Business and Social Science, 6(4), 152-165. Retrieved from http://ijbssnet.com/journal /index/3132.

Amalia, S. R., \& Widodo, A. N. A. (2018). Analisis kemampuan pemecahan masalah mahasiswa melalui model PBL berbasis etnomatematika 
ditinjau dari kepribadian topologi hippocrates dan galenus tipe cholearis dan phlegmantis. Aksioma: Jurnal Matematika dan Pendidikan Matematika, 9(1), 1-10 http:/ / doi.org/10.26877/aks.v9i1.2467.

Arvanitakis, J., \& Hornsby, D. (2016). Universities, the citizen scholar and the future of higher education. Springer.

Balacheff, N. (2010). Bridging knowing and proving in mathematics: a didactical perspective. In Explanation and proof in mathematics. Springer, Boston, MA. 115-135. https://doi.org/10.1007/978-1-4419-0576-5_9.

Basturk, S. (2010). First-year secondary school mathematics students' conceptions of mathematical proofs and proving. Educational Studies, 36(3), 283-298. https:/ / doi.org/10.1080/03055690903424964.

CadwalladerOlsker, T. (2011). What do we mean by mathematical proof?. Journal of Humanistic Mathematics, 1(1), 33-60. https:/ / doi.org/10.5642/ jhummath.201101.04.

Dilla, S. C., Hidayat, W., \& Rohaeti, E. E. (2018). Faktor gender dan resiliensi dalam pencapaian kemampuan berpikir kreatif matematis siswa SMA. Journal of Medives: Journal of Mathematics Education IKIP Veteran Semarang 2(1), 129-136. https://doi.org/10.31331/medives.v2i1.553.

Ersoy, E. (2016). Problem solving and its teaching in mathematics. The Online Journal of New Horizons in Education, 6(2), 79-87. Retrieved from https:/ / www.tojned.net/journals/tojned/articles/v06i02/v06i02-11.pdf.

Gay, L. R. dan Diehl, PL (1992), Research methods for business and management, New York: MacMillan Publishing Company.

Gurat, M. G. (2018). Mathematical problem-solving strategies among student teachers. Journal on Efficiency and Responsibility in Education and Science, 11(3), 53-64. https:/ / doi.org/10.7160/eriesj.2018.110302.

Hanna, G., \& Barbeau, E. (2010). Proofs as bearers of mathematical knowledge. in Explanation and Proof in Mathematics: Philosophical and Educational Perspectives. 85-99. https:/ / doi.org/10.1007/978-1-4419-0576-5.

Hasan, B. (2016). Proses berpikir mahasiswa dalam mengkonstruksi bukti menggunakan induksi matematika berdasarkan teori pemerosesan informasi. APOTEMA: Jurnal Program Studi Pendidikan Matematika, 2(1), 33-40. Retrieved from http://www.jurnal.stkippgri-bkl.ac.id/index.php /APM/article/view/304.

Hastuti, T. D., \& Sari, S. (2018). Student profile with high adversity quotient in math learning. JPhCS, 983(1), http:/ / doi.org/10.1088/1742-6596/983/ 1/012131.

Herutomo, R. A. (2019). Kesalahan mahasiswa dalam pembuktian matematik. Jurnal Didaktik Matematika,6(1), 53-67. https://doi.org/10.24815/jdm. v6i1.13262.

Indarwati, D., Wahyudi, W., \& Ratu, N. (2014). Peningkatan kemampuan pemecahan masalah matematika melalui penerapan problem based 
learning untuk siswa kelas V SD. Satya Widya, 30(1), 17-27. https:// doi.org/10.24246/j.sw.2014.v30.i1.p17-27.

Lesseig, K., Hine, G., Na, G. S., \& Boardman, K. (2019). Perceptions on proof and the teaching of proof: A comparison across preservice secondary teachers in Australia, USA and Korea. Mathematics Education Research Journal, 31(4), 393-418. https:/ / doi.org/10.1007/s13394-019-00260-7.

Liljedahl, P., Santos-Trigo, M., Malaspina, U., \& Bruder, R. (2016). Problem solving in mathematics education. In Problem Solving in Mathematics Education. Springer, Cham. 1-39. https://doi.org/10.1007/978-3-31940730-2.

Maharani, S., \& Bernard, M. (2018). Analisis hubungan resiliensi matematik terhadap kemampuan pemecahan masalah siswa pada materi lingkaran. JPMI (Jurnal Pembelajaran Matematika Inovatif), 1(5), 819-826. http://doi.org/10.22460/jpmi.v1i5.p819-826.

Malik, I., Mulyono, M., \& Mariani, S. (2019). Ability in mathematics problem solving based on adversity quotient. Jurnal Profesi Keguruan, 5(1), 90-95. https:// doi.org/10.7290/jpk.v5i1.18878.

Mardika, F., \& Insani, S. U. (2017). Adversity quotient and students' problem solving skill in mathematics. 4th ICRIEMS Proceedings. Published by The Faculty of Mathematics and Natural Sciences Yogyakarta State University.

Matore, M. E. E. M., Khairani, A. Z., \& Razak, N. A. (2015). The influence of aq on the academic achievement among malaysian polytechnic students. International Education Studies, 8(6), 69-74. http://doi.org/10.5539/ies. v8n6p69.

Mukmin, M. I., \& Fa'ani, A. M. (2020). Identification of students' misconceptions in proving onto and one-to-one function in abstract algebra using certainty response index. International Journal on Teaching and Learning Mathematics, 2(1), 1. https:// doi.org/10.18860/ijtlm. v2i1.8582.

Muliawati, N. E. (2018). Proses berpikir mahasiswa dalam memecahkan masalah pembuktian grup berdasarkan langkah polya. JP2M (Jurnal Pendidikan dan Pembelajaran Matematika), 4(2), 32-42. http://doi.org/10. 29100/jp2m.v4i2.954.

Mulyati, T. (2011). Kemampuan pemecahan masalah matematis siswa sekolah dasar. Jurnal Pendidikan Dasar. 3(2). 35-46. https:/ / doi.org/10.17509/eh. v3i2.2807.

Murphey, D., Barry, M., \& Vaughn, B. (2013). Positive mental health: resilience. Adolescent Health Highlight, 3, 1-6. Retrieved from https://www. childtrends.org/publications/positive-mental-health-resilience.

Mustafia, I. D., \& Widodo, S. A. (2018). Problem solving skill: effectiveness on think pair share with comic. International Journal on Teaching and Learning Mathematics, 1(2), 76-83. http:// doi.org/10.18860/ijtlm.v1i2. 7181. 
Ningsih, S. C. (2017). Meningkatkan kemampuan pemecahan masalah mahasiswa pendidikan matematika UPY pada mata kuliah teori bilangan melalui model pembelajaran creative problem solving (CPS). Jurnal Mercumatika. 1(2). 132-138. https://doi.org/10.26486/mercumatika. v1i2.212.

Novianti, E., \& Kurniadi, Y. (2016). Pendekatan Eksploratif untuk meningkatkan kemampuan pemecahan masalah matematis dan motivasi belajar siswa. Jurnal Pena Ilmiah, 1(1), 401-410. https:/ / doi.org/10.23819/ pi.v1i1.3046.

Nurrahmah, A., \& Karim, A. (2018). Analisis kemampuan pembuktian matematis pada matakuliah teori bilangan. Jurnal eDuMath, 4(2), 21-29. https://doi.org/10.26638/je.753.2064.

Obersteiner, A., Reiss, K., \& Heinze, A. (2018). Psychological theories in mathematics education. Journal für Mathematik-Didaktik, 39, 1-6. https:/ / doi.org/10.1007/s13138-018-0134-3.

Octaria, D., \& Sari, E. F. P. (2017). Kemampuan pemecahan masalah matematis melalui problem based learning. Jurnal Dosen Universitas PGRI Palembang, 1(9), 1-14. https://jurnal.univpgri-palembang.ac.id/index. php/prosiding/article/view/1688.

Oliveros, J. C. (2014). Adversity quotient and problem-solving skills in advanced algebra. JPAIR Multidisciplinary Research, 17(1). http:/ / doi.org /10.7719/jpair.v17il.282.

Ozdemir, E., \& Ovez, F. T. D. (2012). A research on proof perceptions and attitudes towards proof and proving: some implications for elementary mathematics prospective teachers. Procedia-Social and Behavioral Sciences, 46, 2121-2125. https:/ / doi.org/10.1016/j.sbspro.2012.05.439.

Parvathy, U., \& Praseeda, M. (2014). Relationship between adversity quotient and academic problems among student teachers. Journal of Humanities and Social Science,19(11), 23-26. Retrieved from https://pdfs. semanticscholar.org/3dfb/f7c8ff92cf1e84fc8c79503cf8fbd4721a79.pdf.

Qin, L., Zhou, Y., \& Tanu, W. T. (2019). The Analysis of mathematics adversity quotient of left behind junior high school students in rural areas. Open Journal of Social Sciences, 7(10), 331. https://doi.org/10.4236/ jss.2019.710028.

Reivich, K., \& Shatte, A. (2002). The resilience factor: 7 essential skills for overcoming life's inevitable obstacles. Broadway books.

Rocha, H. (2019). Mathematical proof: from mathematics to school mathematics. Philosophical Transactions of the Royal Society A, 377 (2140), 20180045. http://doi.org/10.1098/rsta.2018.0045.

Rojas, L. F. (2015). Factors affecting academic resilience in middle school students: A case study. Gist: Education and Learning Research Journal, (11), 63-78. https://doi.org/10.26817/16925777.286. 
Roscoe, J. T. (1975). Fundamental research statistics for the behavioral sciences (Internasional Series in Decision Processes). Holt, Rinehart \& Winston.

Rostika, D., \& Junita, H. (2017). Peningkatan kemampuan pemecahan masalah siswa SD dalam pembelajaran matematika dengan model diskursus multy representation (DMR). EduHumanioral Jurnal Pendidikan Dasar Kampus Cibiru, 9(1), 35-46. https://doi.org/10.17509/eh.v9i1.6176.

Rukmana, I., Hasbi, M., \& Paloloang, B. (2016). Hubungan adversity quotient dengan hasil belajar matematika siswa kelas XI SMA Negeri Model Terpadu Madani Palu. Jurnal Elektronik Pendidikan Matematika Tadulako, 3(3). Retrieved from http://jurnal.untad.ac.id/jurnal/index. php/JEPMT/article/view/7220.

Star, J. \& Rittle-Johnson, B. (2016). Toward an educational psychology of mathematics education. In L. Corno \& E. Anderman (Eds.) Handbook of Educational Psychology. Third edition. American Psychological Association. New York, United States: Routledge.

Stefanowicz, A., Kyle, J., \& Grove, M. (2014). Proofs and mathematical reasoning. University of Birmingham.

Stoltz, P. G. (2004). Adversity quotient: mengubah hambatan menjadi peluang. Jakarta: Gramedia Widiasarana Indonesia.

Suhendri, H. (2018). The role of resilience (adversity intelligence) and creativity in mathematics learning. Unnes Journal of Mathematics Education, 7(2), 9094. https:// doi.org/10.15294/ujme.v7i2.25367.

Supardi, U. S. (2014). Pengembangan Instrumen Pengukuran Ketahanmalangan (Kecerdasan Adversitas) Siswa. In Prosiding Seminar Nasional Evaluasi Pendidikan Program Pacsasarjana UNJ. 978-608. Jakarta.

Zanthy, L. S. (2018). Kontribusi resiliensi matematis terhadap kemampuan akademik mahasiswa pada mata kuliah statistika matematika. Mosharafa: Jurnal Pendidikan Matematika,7(1), 85-94. https://doi.org/10.31980/ mosharafa.v7i1.344. 